\title{
Retrospective study investigating the prevalence and clinical significance of hepatitis B virus precore and basal core promoter variants
}

\author{
Meaghan O'Brien MD FRCPC ${ }^{1}$, Adara Casselman BSc², Gerry Smart BSc MLT², Ainsley Gretchen BSc ${ }^{2}$, \\ Kelly Kaita MD FRCPC ${ }^{3}$, Kamran Kadkhoda PhD FCCM D(ABMM) ${ }^{2,4}$
}

M O’Brien, A Casselman, G Smart, A Gretchen, K Kaita, $\mathrm{K}$ Kadkhoda. Retrospective study investigating the prevalence and clinical significance of hepatitis $\mathrm{B}$ virus precore and basal core promoter variants. Can J Gastroenterol Hepatol 2015;29(8):e1-e6.

BACKGROUND: Hepatitis B virus (HBV) precore (PC) and basal core promoter $(\mathrm{BCP})$ variants are well known; however, their prevalence in North America is unclear, especially among hepatitis B e antigen-negative patients.

OBJECTIVE: To investigate the prevalence of $\mathrm{PC} / \mathrm{BCP}$ mutations and their clinical significance.

METHODS: One hundred twenty-eight patients positive for both hepatitis B surface antigen and hepatitis B e antibody were selected, and $\mathrm{PC} / \mathrm{BCP}$ mutations were identified using a line probe assay. The subjects' charts were reviewed for race/ethnicity, HBV genotype, HBV viral load, sex, liver enzyme levels, imaging and biopsy results up to 10 years before the study.

RESULTS: The prevalence of PC and BCP variants were $47.6 \%$ and $62.5 \%$, respectively. Older age was associated with aspartate aminotransferase-to-platelet index ratio $(\mathrm{APRI}) \geq 0.7(\mathrm{P}=0.011)$ and abnormal imaging/biopsy results $(\mathrm{P}=0.0008)$. Although the presence of $\mathrm{BCP}$ variant(s) was associated with $A P R I \geq 0.7(P=0.029)$, it was not associated with abnormal imaging/biopsy results. The combination of age $\geq 50$ years and the presence of BCP variant(s) was associated with abnormal imaging/biopsy results, suggestive of either cirrhosis or hepatocellular carcinoma (not observed with PC mutation). Neither sex or genotype, or median HBV viral load showed significant influence on any of these outcomes.

CONCLUSIONS: The present study suggests that the prevalence of $\mathrm{PC}$ and $\mathrm{BCP}$ mutations are higher than what has been previously reported. One potential explanation would be increased immigration in the past decade. Considering the potential public health and clinical implications of these variants, long-term multicentre and prospective studies could further unravel the uncertainty around these variants.

Key Words: Canada; Clinical significance; Precore mutations

L epatitis B virus (HBV) contains a core gene that is divided into two 1 parts - the precore (PC) and core regions. Mutations can occur in either region, culminating in a $\mathrm{PC}$ mutant or a basal core promoter (BCP) mutant, respectively. Mutations in the $\mathrm{PC}$ region (particularly at position G/A 1896) are primarily nonsense or frameshift mutations, or mutated initiation codons, whereas mutations in the BCP region (particularly dual mutations at positions 1762 and 1764, the so-called 'TA change') are primarily missense substitutions $(1,2)$. These mutations

\section{Une étude rétrospective sur la prévalence et la signification clinique des variantes du gène précore et du promoteur du core basal du virus de l'hépatite $B$}

HISTORIQUE : Les variantes du gène précore $(\mathrm{PC})$ et du promoteur du core basal (PCB) du virus de l'hépatite $\mathrm{B}(\mathrm{VHB})$ sont bien connues. On n'en connaît toutefois pas la prévalence en Amérique du Nord, particulièrement chez les patients non porteurs de l'antigène e de l'hépatite B.

OBJECTIF : Examiner la prévalence et la signification clinique des mutations PC et PCB.

MÉTHODOLOGIE : Les chercheurs ont sélectionné 128 patients porteurs de l'antigène de surface de l'hépatite $B$ et de l'anticorps e de l'hépatite $\mathrm{B}$ et ont repéré les mutations $\mathrm{PC}$ et $\mathrm{PCB}$ au moyen d'une sonde linéaire. Ils ont vérifié la race ou l'ethnie des patients, le génotype du VHB, la charge virale du VHB, leur sexe, leurs taux d'enzyme hépatique, les résultats de l'imagerie et des biopsies jusqu'à dix ans avant l'étude.

RÉSULTATS : La prévalence de variantes PC et PCB s'élevait à 47,6\% et à $62,5 \%$, respectivement. Un âge avancé était lié à un coefficient d'indexation entre l'aspartate aminotransférase et les plaquettes (APIR) d'au moins $0,7(\mathrm{P}=0,011)$ et à des résultats d'imagerie ou de biopsie anormaux $(\mathrm{P}=0,0008)$. Même si la présence de variante(s) des PCB s'associait à un APIR d'au moins 0,7 (P=0,029), il n'était pas relié à des résultats d'imagerie ou de biopsie anormaux. La combinaison d'un âge d'au moins 50 ans et de la présence de variante(s) PCB s'associait à des résultats d'imagerie et de biopsie anormaux, indicateurs d'une cirrhose ou d'un carcinome hépatocellulaire (non observé dans la mutation PC). Ni le sexe ni le génotype ni la charge virale médiane du VHB n'avaient d'influence significative sur ces résultats.

CONCLUSIONS : D’après la présente étude, la prévalence des mutations PC et PCB est plus élevée que ce qui a été déclaré par le passé. Laugmentation du taux d'immigration depuis dix ans pourrait contribuer à expliquer ce phénomène. Étant donné les conséquences potentielles de ces variantes pour la santé publique et les résultats cliniques, des études multicentriques et prospectives à long terme pourraient décortiquer les incertitudes entourant ces variantes.

lead to loss of expression of the hepatitis B e antigen ( $\mathrm{HBeAg}$ ) or a significant reduction in its production and secretion. The presence of $\mathrm{HBeAg}$ normally elicits an anti-HBeAg immune response. This immune response causes, for the most part, a desired reduction in HBV viral load, but selects variants that have little or no HBeAg expression such as those produced by PC or BCP mutations (1). To detect these mutations, a range of methodologies, including direct sequencing, restriction fragment length polymorphism (3) and line probe assay

${ }^{1}$ Department of Internal Medicine, Upper River Valley Hospital, Waterville, New Brunswick; ${ }^{2}$ Serology Section, Cadham Provincial Public Health

Laboratory; ${ }^{3}$ Section of Hepatology, Department of Internal Medicine, College of Medicine, Faculty of Health Sciences, University of Manitoba;

${ }^{4}$ Department of Medical Microbiology $\mathcal{E}$ Infectious Diseases; and Department of Immunology, College of Medicine, Faculty of Health Sciences,

University of Manitoba, Winnipeg, Manitoba

Correspondence: Dr Kamran Kadkhoda, Serology Section, Cadham Provincial Public Health Laboratory, 750 William Avenue, Winnipeg, Manitoba R3C 3Y1 .

Telephone 204-945-7545, e-mail kamran.kadkhoda@gov.mb.ca

Received for publication June 10, 2015. Accepted July 25, 2015 
(LiPA) $(4,5)$, have been developed, the latter being more sensitive in detecting variants than direct sequencing (5). Studies have shown a significant geographical variation in the prevalence of PC and BCP mutants, with some of the lowest prevalence rates being found in North America (6). Prevalence rates for PC mutants range from $0 \%$ to $100 \%$, with most approximately $60 \%$. Prevalence rates for BCP mutations range from $50 \%$ to $77 \%$; however, these studies were either metaanalyses or performed outside of North America (6-8). The most recent comprehensive study investigating $\mathrm{PC} / \mathrm{BCP}$ variants in North America was conducted in the United States by the HBV Epidemiology Study Group and was published in 2003 (9). Since then, no thorough studies have been performed, particularly in anti-HBe-positive patients. This is despite the fact that significant immigration to North America from endemic countries has occurred since then and may have culminated in the current findings. To date, only one study has assessed the prevalence of PC mutations in Canada (10), and that study only examined 30 Canadian Inuit patients. To date, no studies have investigated the prevalence of BCP mutations in Canada; however, there is evidence to suggest that the presence of mutants affects the natural history of HBV infection. Studies have shown that PC and BCP mutations may be associated with poorer clinical outcomes including a higher risk for cirrhosis and hepatocellular carcinoma (HCC), although results have been conflicting (11-15).

The primary aim of the present study, therefore, was to determine the prevalence of BCP and PC mutations in Manitoba in individuals chronically infected with HBV and who are anti-HBe positive. The study also aimed to determine whether a correlation exists between the presence of a mutant and HBV disease severity, including progression to cirrhosis and development of HCC.

\section{METHODS}

\section{Study design}

In the present study, 128 residual plasma specimens that were submitted to Cadham Provincial Laboratory (CPL, Winnipeg, Manitoba) from September 2010 through May 2014 for HBV viral load testing as well as HBV genotyping were chosen. Using the residual specimens, the prevalence of PC and BCP mutations were determined, and this information was linked to the subjects' other clinical and laboratory parameters. Most of subjects had a relatively long history of testing; however, past specimens were not available to be reanalyzed. CPL is the provincial public health laboratory in Manitoba that performs HBV viral load testing for the province, while referring out HBV genotyping requests to the National Microbiology Laboratory in Winnipeg (Manitoba).

Inclusion criteria were: age $\geq 18$ years; hepatitis B surface antigen positive; HBeAg negative and anti-HBeAg positive; any HBV viral load test performed and, preferably, HBV genotype known (however, 30 samples without known HBV genotypes were genotyped in the authors' laboratory for the present study). Subjects coinfected with hepatitis $\mathrm{C}$ virus (HCV), hepatitis D virus and HIV were excluded. None of, sex, race/ethnicity and HBV genotype was used as inclusion or exclusion criteria. A retrospective chart review was performed to collect up to 10 years (where applicable) of additional clinical and laboratory information including race/ethnicity, sex, liver enzyme data (alanine aminotransferase [ALT], aspartate aminotransferase [AST]), platelet counts, imaging and liver biopsy results. Median HBV viral load, ALT and AST levels, and platelet counts were collected for each subject. Median AST-to-platelet index ratio (APRI) was calculated for each subject (where available) using the following formula:

\section{Median AST/ULN $\times 100 /$ median platelet count}

in which the upper limit of normal (ULN) for AST was defined as $32 \mathrm{U} / \mathrm{L}$. Abnormal ALT level was based on the reference ranges provided by the testing laboratory: $<25 \mathrm{U} / \mathrm{L}$ for females and $<30 \mathrm{U} / \mathrm{L}$ for males. Only $17 \%$ of patients had any treatment history. Patients with fatty liver disease, autoimmune hepatitis and other non-HBV-related causes were excluded on chart review. Abnormal liver biopsy results were defined as fibrosis stage $\geq 2$ (METAVIR $\mathrm{F} \geq 2$ ) or HCC according to pathology report. Abnormal liver imaging was defined as a computed tomography scan, magnetic resonance imaging scan or an ultrasound radiology report of irregular hepatic surface/contour, or regenerative hepatic nodules with or without portal hypertension measured using Doppler. The study was approved by the University of Manitoba Research Ethics Board \#H2014:125.

\section{HBV viral load}

Quantitative HBV DNA levels (or HBV viral loads) were previously determined at the CPL using COBAS AmpliPrep/COBAS TaqMan HBV Test (Roche Diagnostics GmbH, Germany) according to the manufacturers' instructions. This product requires $650 \mu \mathrm{L}$ of plasma specimen, has a limit of detection of $20 \mathrm{IU} / \mathrm{mL}$, a dynamic range of $20 \times 10^{8} \mathrm{IU} / \mathrm{mL}$ to $1.7 \times 10^{8} \mathrm{IU} / \mathrm{mL}$, and covers all eight HBV genotypes (A through $\mathrm{H}$ ). For consistency, only EDTA-plasma is accepted for this test.

\section{HBV genotyping}

HBV genotyping was referred to the National Microbiology Laboratory in Winnipeg, where genotyping is performed by either direct sequencing or INNO-LiPA HBV Genotyping kit (Innogenetics, Fujirebio, Japan). Thirty specimens had met inclusion criteria but did not have known HBV genotypes. These genotypes were determined using the INNO-LiPA HBV Genotyping kit (Innogenetics, Fujirebio). Briefly, HBV DNA was extracted from specimens $(200 \mu \mathrm{L})$ using the easyMAG system (bioMérieux, France). Amplification was performed using Platinum Taq DNA Polymerase (Life Technologies, USA). The volume of water was adjusted because the $\mathrm{MgCl}_{2}$ reagent is separate (final concentration $1.5 \mathrm{mM}$ ). The dNTPs were combined in equal volumes to yield a dNTP mixture of $25 \mathrm{mM}$ each. The master mixes and cycling parameters were followed as per product insert for outer and nested amplification. The thermocycler used was an Eppendorf AG Mastercycler ep (Eppendorf, USA). The LiPA was performed on a Med/TEC AutoBlot 3000H (Fujirebio, Japan) following the automation protocol for this instrument.

\section{HBV PC/BCP mutations}

HBV PC (G1896A) and BCP (A1762T, G1764A) mutation testing was performed using the INNO-LiPA HBV PreCore kit (Innogenetics, Fujirebio). Briefly, HBV DNA was extracted from samples $(200 \mu \mathrm{L})$ using easyMAG system (bioMérieux); the final elution volume was $25 \mu \mathrm{L}$. Amplification used Platinum Taq DNA Polymerase (Life Technologies) and $100 \mathrm{mM}$ dNTP set. The volume of water was adjusted because the $\mathrm{MgCl}_{2}$ reagent is separate $(1.5 \mu \mathrm{L}$ final concentration $1.5 \mathrm{mM})$. The dNTPs were combined in equal volumes to yield a dNTP mixture of $25 \mathrm{mM}$ each. The master mixes and cycling parameters were followed as per product insert for outer and nested amplification. The thermocycler used was an Eppendorf AG Mastercycler ep (Eppendorf). LiPA was performed on a Med/TEC AutoBlot $3000 \mathrm{H}$ (Fujirebio) following the automation protocol for this instrument.

\section{Statistical analyses}

Data were analyzed using Analyse-it (Analyse-it Software, Ltd, United Kingdom) for Excel version 2.0 (Microsoft Corporation, USA). Statistical analyses were performed using the Fisher's exact test (including OR calculation and 95\% CIs) and Mann-Whitney U test for categorical variables. Results were considered to be statistically significant at $\mathrm{P}<0.05$.

\section{RESULTS}

One hundred twenty-eight specimens chosen from subjects who met the inclusion criteria were studied. Subjects belonged to three major ethnicities: Asian (71\%), non-Hispanic white (10\%) and African descent (19\%). Of an initial 132 specimens, four were excluded because two did not have amplified DNA for genotyping and PC/BCP mutation testing and two were positive for $\mathrm{HCV}$ or hepatitis $\mathrm{D}$ virus. The age range was 18 to 80 years, with a median age of 40 years. Fiftyfive percent of subjects were male and $45 \%$ were female. Of eight known HBV genotypes (A through $\mathrm{H}$ ) only five were present: A 
TABLE 1

Demographics, laboratory abnormalities and any abnormal liver findings according to imaging or biopsy versus precore (PC)/basal core promoter (BCP) mutations

\begin{tabular}{|c|c|c|c|c|}
\hline \multirow[b]{2}{*}{ Variable } & \multicolumn{2}{|c|}{ Mutation } & \multirow[b]{2}{*}{$\mathbf{P}$} & \multirow[b]{2}{*}{ Statistical test } \\
\hline & $\mathrm{PC}$ & BCP & & \\
\hline Patient population & $61 / 128(47.6)$ & $80 / 128(62.5)$ & & Not applicable \\
\hline Age, years & $41.27 \pm 13.37$ & $41.25 \pm 13.42$ & 0.099 & Mann-Whitney \\
\hline Male sex & $37 / 61(60.6)$ & $8 / 80(60)$ & 1.00 & Fisher's exact \\
\hline Abnormal median ALT level & $30 / 61(49.1)$ & $46 / 79(58.2)$ & 0.66 & Fisher's exact \\
\hline Abnormal median AST level & $16 / 61(26.2)$ & $26 / 79(32.9)$ & 0.65 & Fisher's exact \\
\hline ALT level, >1.5×upper limit of normal & 29/61(47.5) & $44 / 79(55.6)$ & 0.69 & Fisher's exact \\
\hline Platelet count, $\times 10^{9} / \mathrm{L}$ & $223 \pm 54$ & $218 \pm 59$ & 0.64 & Mann-Whitney \\
\hline $\mathrm{APRI} \geq 0.7$ & $8 / 61(13.1)$ & $17 / 78(21.7)$ & 0.37 & Fisher's exact \\
\hline Abnormal liver imaging and/or biopsy & $22 / 59(37.2)$ & $32 / 75(42.6)$ & 0.80 & Fisher's exact \\
\hline Hepatitis B virus viral load, median, $\log _{10} \mathrm{IU} / \mathrm{mL}$ & 3.49 & 3.49 & & Not applicable \\
\hline
\end{tabular}

Data presented as $n / n$ (\%) or mean $\pm S D$ unless otherwise indicated. Abnormal liver biopsy results were defined as fibrosis stage $\geq 2$ (METAVIR F $\geq 2$ ) or hepatocellular carcinoma according to the pathology report. Abnormal liver imaging was defined as a computed tomography scan, magnetic resonance imaging or an ultrasound radiology report of irregular hepatic surface/contour, or regenerative hepatic nodules with/without portal hypertension measured by Doppler. ALT Alanine aminotransferase; APRI Aspartate aminotransferase (AST)-to-platelet ratio index

(36.7\%), B (17.1\%), C (23.4\%), D (14\%) and E (8.5\%). The distribution of HBV genotypes among different race/ethnicities were as follows: Asians: $35.1 \% \mathrm{~A}, 24.1 \% \mathrm{~B}, 31.8 \% \mathrm{C}, 8.7 \% \mathrm{D}$ and $0 \% \mathrm{E}$; non-Hispanic whites: $38.4 \% \mathrm{~A}, 0 \% \mathrm{~B}, 7.6 \% \mathrm{C}, 53.8 \% \mathrm{D}$ and $0 \% \mathrm{E}$; and African descent: $41.6 \%$ A, 0\% B, 0\% C, 12.5\% D and 45.8\% E.

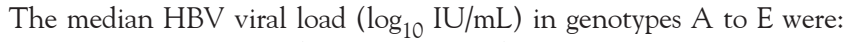
$3.48,3.49,3.46,3.48$ and 3.48 , respectively.

PC/BCP mutations and demographics

The prevalence of $\mathrm{PC}$ and BCP mutations were higher in the present study compared with those previously reported (15). The overall prevalence of $\mathrm{PC}$ and $\mathrm{BCP}$ mutations was $46.7 \%$ and $62.5 \%$, respectively. The distribution of PC mutation (G1896A) in subjects with HBV genotypes A through E was 6.3\%, 95.4\%, 40\%, 77.7\% and $100 \%$, respectively. The distribution of BCP (A1762T, G1764A) dual mutation in subjects with HBV genotypes $\mathrm{A}$ through $\mathrm{E}$ was: $61.7 \%$, $36.3 \%, 80 \%, 66.6 \%$ and $63.6 \%$, respectively. In Asian, African descent and non-Hispanic white racial/ethnic groups, the prevalence of PC mutation was: $46.1 \%, 54.1 \%$ and $46.1 \%$, respectively. The prevalence of BCP dual mutation in the above racial/ethnic groups was: $62.6 \%, 62.5 \%$ and $61.5 \%$, respectively. The mean ( \pm SD) age of subjects with $\mathrm{PC}$ and $\mathrm{BCP}$ mutations was $41.27 \pm 13.37$ and $41.25 \pm 13.42$ years, respectively $(\mathrm{P}=0.99)$. The prevalence of $\mathrm{PC}$ and $\mathrm{BCP}$ mutations in males was $60.6 \%$ and $60 \%$, respectively $(\mathrm{P}=1.00)$ (Table 1$)$. It should be noted, however, that the estimated prevalence of HBVrelated cirrhosis in Manitoba is up to 5\%, while the incidence of HBVrelated $\mathrm{HCC}$ is up to $1 \%$.

PC/BCP mutations, HBV viral load and laboratory abnormalities Of subjects with PC or BCP mutations, $49.1 \%$ and $58.2 \%$ had an abnormal median ALT value, respectively $(\mathrm{P}=0.66)$, whereas those with an abnormal median AST value were $26.2 \%$ and $32.9 \%$, respectively $(\mathrm{P}=0.65)$. Median ALT values of $\geq 1.5 \times \mathrm{ULN}$ were present in $47.5 \%$ and $55.6 \%$ of those with $\mathrm{PC}$ and $\mathrm{BCP}$ mutations, respectively $(\mathrm{P}=0.69)$. The mean platelet count in those with $\mathrm{PC}$ or BCP mutations was $233 \pm 54 \times 10^{9} / \mathrm{L}$ and $218 \pm 59 \times 10^{9} / \mathrm{L}$, respectively $(\mathrm{P}=0.64)$. An APRI $\geq 0.7$ was present in $13.1 \%$ and $21.7 \%$ of individuals with PC and $\mathrm{BCP}$ mutations, respectively $(\mathrm{P}=0.37)(\mathrm{OR} 1.66[95 \% \mathrm{CI} 0.67$ to 4.10]). Individuals with $\mathrm{PC}$ or BCP mutations had equal median HBV viral loads of $3.49 \log _{10} \mathrm{IU} / \mathrm{mL}$ (Table 1). Neither PC nor BCP mutations were significantly associated with median HBV viral load (data not shown).

PC/BCP mutations and abnormal liver imaging and/or biopsy Abnormal liver imaging and/or biopsy results were found in $37.2 \%$ and 42.6\% with PC and BCP mutations, respectively $(\mathrm{P}=0.80)$ (Table 1$)$.
TABLE 2

Factors associated with an aspartate aminotransferase-toplatelet ratio index $\geq 0.7$

\begin{tabular}{|c|c|c|c|c|}
\hline Factor & $\begin{array}{c}\text { Patients, } \\
\mathrm{n} / \mathrm{n}\end{array}$ & OR (95\% Cl) & Statistical test & $\mathbf{P}$ \\
\hline Sex & & $2.27(0.77-6.69)$ & Fisher's exact & 0.20 \\
\hline Male & $14 / 69$ & & & \\
\hline Female & $5 / 56$ & & & \\
\hline
\end{tabular}

Hepatitis B virus genotype

\begin{tabular}{lcccl} 
A & $5 / 44$ & $1.52(0.51-4.5)$ & Fisher's exact & 0.62 \\
$\mathrm{~B}$ & $0 / 22$ & $\mathrm{~N} / \mathrm{A}$ & Fisher's exact & 0.06 \\
$\mathrm{C}$ & $8 / 30$ & $0.43(0.16-1.17)$ & Fisher's exact & 0.17 \\
$\mathrm{D}$ & $4 / 18$ & $0.63(0.18-2.11)$ & Fisher's exact & 0.64 \\
$\mathrm{E}$ & $2 / 11$ & $0.82(0.16-4.02)$ & Fisher's exact & 1.00 \\
Age $^{*}$ & $19 / 125$ & $\mathrm{~N} / \mathrm{A}$ & Mann-Whitney & $0.011^{\dagger}$ \\
$\mathrm{PC}$ mutation & $8 / 61$ & $0.76(0.28-2.02)$ & Fisher's exact & 0.76 \\
$\mathrm{BCP}$ mutation & $17 / 78$ & $5.12(1.13-23.16)$ & Fisher's exact & $0.029^{\dagger}$ \\
$\begin{array}{l}\text { Age } \geq 50 \text { years } \\
\text { and BCP }\end{array}$ & $11 / 28$ & $6.67(0.79-56.42)$ & Fisher's exact & 0.096 \\
mutation & & & & \\
\hline
\end{tabular}

${ }^{*}$ Median difference 10.0 (95\% Cl 3.0 to 18.0$)$, older age was significantly associated with an aspartate aminotransferase-to-platelet ratio $\geq 0.7$; †Statistically significant. BCP Basal core promoter; N/A Not applicable; PC Precore

Association of APRI $\geq 0.7$ with age, sex and $\mathrm{HBV}$ genotype An APRI $\geq 0.7$ was chosen because those with APRI $\geq 0.7$ had significantly more abnormal liver imaging and/or biopsy findings compared with those with APRI $<0.7$ (OR 2.4 [95\% CI 1 to 5.7]; $\mathrm{P}=0.03$ ). Additionally, in HCV-infected individuals, this cut-off has been deemed reasonable (16). Although $20.2 \%$ of males had an APRI $\geq 0.7$, only $8.9 \%$ of females had an APRI $\geq 0.7$; however, no statistical significance was found (OR 2.27 [95\% CI 0.77 to 6.69]; $\mathrm{P}=0.20$ ). HBV genotypes were compared for the presence of APRI $\geq 0.7$ and no statistical significance was noted (Table 2). Age was an independent factor affecting APRI, with older age being associated with APRI $\geq 0.7$ (median difference 10 years [95\% CI 3.0 to 18.0 ]; $\mathrm{P}=0.011$ ) (Table 2).

Association of $\mathrm{APRI} \geq 0.7$ with $\mathrm{PC} / \mathrm{BCP}$ mutations and combination of age $\geq 50$ years and $\mathrm{BCP}$ mutations

Individuals with a G1896A point mutation did not have a significantly higher proportion of APRI $\geq 0.7$, but in fact showed a relative, but nonsignificant protective effect ( $\mathrm{OR} 0.76$ [95\% CI 0.28 to 2.02]; $\mathrm{P}=0.76$ ). However, those with a BCP dual mutation had a significantly higher 


\begin{tabular}{|c|c|c|c|c|}
\hline Factor & $\begin{array}{c}\text { Patients, } \\
n / n\end{array}$ & OR $(95 \% \mathrm{Cl})$ & Statistical test & $\mathbf{P}$ \\
\hline Sex & & $2.23(1.02-4.86)$ & Fisher's exact & 0.059 \\
\hline Male & $30 / 66$ & & & \\
\hline Female & $11 / 54$ & & & \\
\hline \multicolumn{5}{|c|}{ Hepatitis B virus genotype } \\
\hline A & $13 / 43$ & $1.20(0.56-2.56)$ & Fisher's exact & 0.77 \\
\hline B & $6 / 21$ & $1.23(0.46-3.31)$ & Fisher's exact & 0.87 \\
\hline C & $15 / 29$ & $0.55(0.25-1.18)$ & Fisher's exact & 0.18 \\
\hline D & $6 / 17$ & $0.96(0.35-2.63)$ & Fisher's exact & 1.00 \\
\hline$E$ & $1 / 10$ & $3.63(0.45-29.31)$ & Fisher's exact & 0.35 \\
\hline Age $^{*}$ & $41 / 120$ & $N / A$ & Mann-Whitney & $0.0008^{\dagger}$ \\
\hline PC mutation & $22 / 59$ & $1.19(0.58-2.43)$ & Fisher's exact & 0.75 \\
\hline BCP mutation & $32 / 75$ & $2.13(0.93-4.87)$ & Fisher's exact & 0.098 \\
\hline $\begin{array}{l}\text { Age } \geq 50 \text { years } \\
\text { AND BCP } \\
\text { mutation }\end{array}$ & $17 / 23$ & $N / A^{\ddagger}$ & Fisher's exact & $0.041^{\dagger}$ \\
\hline
\end{tabular}

*Median difference 9.0 (95\% Cl 4.0-14.0), older age was significantly associated with abnormal liver imaging suggestive of cirrhosis/hepatocellular carcinoma and/or abnormal finding on liver biopsy; ${ }^{\dagger}$ Statistically significant; ¥No patients in the wild type group. BCP Basal core promoter; NA Not applicable; PC Precore

proportion of $\mathrm{APRI} \geq 0.7$ (OR 5.12 [95\% CI 1.13 to 23.16]; $\mathrm{P}=0.029$ ), suggesting that a $\mathrm{BCP}$ dual mutation is an independent and relatively strong factor in elevating APRI. Finally, a combination of BCP dual mutation and age $\geq 50$ years showed a borderline nonstatistical significance with APRI $\geq 0.7$ (OR 6.67 [95\% CI 0.79 to 56.42];P=0.096) (Table 2).

\section{Association of abnormal liver imaging and/or biopsy with age, sex} and HBV genotype

Abnormal liver imaging and/or biopsy results were found in $45.4 \%$ of men, but only $20.3 \%$ of women had such results (OR 2.23 [95\% CI 1.02 to 4.86]); however, the difference was nearly significant $(\mathrm{P}=0.059)$. Similar to what was observed with APRI $\geq 0.7$, HBV genotypes did not affect liver imaging and/or biopsy results (Table 2). However, older age was associated with abnormal liver imaging and/or biopsy results, with a median difference of nine years (95\% CI 4.0 to 14.0) $(\mathrm{P}=0.0008)$.

Association of abnormal liver imaging and/or biopsy with $\mathrm{PC} / \mathrm{BCP}$ mutations and combination of age $\geq 50$ years and $\mathrm{BCP}$ mutations Those with a G1896A point mutation did not have a higher proportion of abnormal liver imaging and/or biopsy results compared with those without the mutation $(\mathrm{P}=0.75)$. Those with $\mathrm{BCP}$ dual mutation also did not have a significantly higher proportion of abnormal liver imaging and/or biopsy results; however, the nonsignificance was relatively marginal $(\mathrm{P}=0.098)$, with OR 2.13 (95\% CI 0.93 to 4.87 ). Finally, the combination of age $\geq 50$ years and BCP dual mutation showed statistical significance with abnormal liver imaging and/or biopsy results compared with those $<50$ years of age and no mutations at postions 1762 and $1764(\mathrm{P}=0.041)$ (Table 3). Lower age cut-offs applied did not yield statistical significance (data not shown).

\section{DISCUSSION}

The natural history of hepatitis B is associated with $\mathrm{HBeAg}$ loss. These patients will generally enter an inactive phase with a percentage of them becoming active with the development of either the $\mathrm{PC}$ or BCP mutation (17). Individuals in the inactive phase tend to have HBV viral loads $<4.3 \log _{10} \mathrm{IU} / \mathrm{mL}$, normal liver enzyme levels, and no to minimal fibrosis on biopsy. However, those in the immune active phase may also have low-level HBV viral loads, especially when on nucleo(t)side analogues and may not have elevated liver enzyme levels. For this reason, we opted to use median viral load and liver enzyme levels to make a better assessment of disease activity over time, if any, in the context of PC/BCP mutations.

The most recent study to determine the prevalence of PC/BCP mutations in North America was performed more than a decade ago. Therefore, the present study serves as more recent and region-specific view on the prevalence of these mutations and sheds further light on their clinical significance. As mentioned in the Results section, the prevalence of both PC and dual BCP mutations was higher than previously reported (9). That study included HBeAg-positive patients but, as indicated earlier, the majority of chronically HBV-infected patients seroconvert to anti-HBe-positive status. This is especially true among immigrants from endemic regions who harbour HBV genotypes with a different distribution of PC/BCP mutations. Our study involved three main racial/ethnic groups: Asian, non-Hispanic white and African descent. The race/ethnicity distribution in our study was different than that of the United States study because no Hispanic whites participated in our study and the African descent subjects consisted mainly of recent immigrants from Africa, with $45 \%$ of them harbouring genotype E. It is also noteworthy to mention that the majority (71\%) of our subjects were of Asian ancestry. There was an even age and sex distribution across the study population. The relatively high prevalence of $\mathrm{PC}$ and BCP mutations are of concern from both a clinical and public health perspective.

It appears that $\mathrm{PC}$ and $\mathrm{BCP}$ mutations are strategies to regain viral fitness in the form of replication capacity in lamivudine-resistant and tenofovir-resistant strains of HBV based on in vitro studies; however, no clinical cases have been reported with tenofovir resistance to date $(18,19)$. From a clinical perspective, BCP mutations have been associated with nonresponse to interferon therapy (19). PC and BCP mutations have also been associated with fulminant hepatitis in HBV-noninfected individuals (21-26), making these mutations of concern from a clinical and public health perspective. Finally, these variants have also been associated with HCC (27-30).

In our study, median ALT and AST were not affected by PC or BCP mutations. Even when abnormal median ALT values $1.5 \times \mathrm{ULN}$ were used, no significance was observed, suggesting that the fluctuation of liver enzyme levels over time could be due to more than the presence of a mutation. This was also the case for median platelet values as a loose measure of liver impairment. Even by combining AST and platelet count (ie, APRI and applying three different cut-offs $[0.5,0.6$ and 0.7]), neither mutation independently affected APRI (data not shown for the first two cut-off values). This could, however, be due to the fact that LiPA is a sensitive method and detects variants even if they constitute a small subpopulation of the quasiviral pool combined with the fact that mutation detection was performed on samples collected between 2010 and 2014. However, the chart review was performed for a period of up to 10 years before the mutations analysis, when they potentially did not carry a mutation. By the same token, abnormal liver imaging and/or biopsy results were not independently affected by the mutations, perhaps because those changes typically occur later in the disease course and, for the most part, are preceded by liver enzyme and platelet count abnormalities; hence, APRI elevation (although the latter association may be weak). Although not statistically significant, but as shown in Table 1, liver enzyme abnormalities, lower platelet counts, abnormal APRI, and abnormal liver imaging and/or biopsy results were consistently more frequent in those with a BCP mutation than a PC mutation. The lack of significance may be due to the relatively cross-sectional nature of the present study and, perhaps, would have resulted in significant results had the study monitored subjects for a longer period because age was significantly associated with APRI $\geq 0.7$ and abnormal liver imaging and/or biopsy results (Table 2). This could be explained by a greater chance of accumulating mutations as age increases. 
Interestingly, despite previous reports (15), median HBV viral load (as a measure of viremia over time in the present study) was not significantly associated with either mutation, suggesting that median HBV viral load cannot be used as a stand-alone parameter to predict adverse outcomes. The contrasting result may be somewhat due to the fact that in the Risk Evaluation of Viral Load Elevation and Associated Liver Disease/Cancer-Hepatitis B Virus (REVEAL) (15) study, the design was different because only those with HBV viral loads $>3.23 \log _{10} \mathrm{IU} / \mathrm{mL}$ were tested for PC/BCP mutation, while we did not use such an inclusion criterion. Additionally, their study was limited to a certain race/ ethnicity and only two HBV genotypes (B and C). However, consistently detectable levels of HBV viral load may increase the theoretical risk for further development of mutations because the higher the viral propagation (which is error prone), the higher the probability of developing a mutation, thereby exerting its adverse outcomes indirectly. This, at least in part, was reflected in a higher (although not significant) proportion of APRI $\geq 0.7$, and significantly higher proportion of imaging and/or biopsy abnormalities in those with both older age ( $\geq 50$ years) and BCP mutation (Table 2).

Male sex is known to be associated with HCC (17). In our study, individuals with abnormal liver imaging and/or biopsy results suggestive of advanced fibrosis, cirrhosis or HCC were grouped together. This may explain why statistical significance was achieved with either of the two_sexes; although male sex showed both higher percentage with APRI $\geq 0.7$ and/or liver imaging/biopsy abnormalities. This may partly be due to a sex bias in referrals and in further investigations (including HBV viral load, genotype, ALT/AST assessments and imaging) as recommended per guidelines for HCC screening or could be due to immunological differences between the two sexes leading to T-helper (Th)1/Th2 balance shifting toward Th1 in men. This could result in a greater chance of immune activation and liver tissue damage, which could lead to repair/regeneration and fibrosis as a consequence; however, this remains controversial (31-33).

Another interesting finding is the absence of an effect of HBV genotypes on clinical outcomes including genotype $\mathrm{C}$, which has been shown to have worse outcomes (16). There are eight genotypes of HBV (A through $\mathrm{H}$ [34-36]). Initially the genotypes were somewhat geographically distinct, with genotype A focused in northern Europe, North America, South America, Australia and Sub-Saharan Africa; genotype B focused in West Africa, southeast Asia, China and Japan; genotype $\mathrm{C}$ focused in Southeast and East Asia, Pacific Islands, Australian Aboriginals and Alaska; genotype D focused in the

\section{REFERENCES}

1. Parekh S, Zoulim F, Ahn SH, et al. Genome replication, virion secretion, and e antigen expression of naturally occurring hepatitis B virus core promoter mutants. J Virol 2003;77:6601-12.

2. Okamoto H, Yotsumoto S, Akahane Y, et al. Hepatitis B viruses with precore region defects prevail in persistently infected hosts along with seroconversion to the antibody against e antigen. J Virol 1990;64:1298-303.

3. Lindh M, Furuta Y, Ljunggren KK, et al. Detection of hepatitis B virus precore TAG mutant by an amplification-created restriction site method. J Infect Dis 1995;171:194-7.

4. Grandjacques C, Pradat P, Stuyver L, et al. Rapid detection of genotypes and mutations in the pre-core promoter and the pre-core region of hepatitis $B$ virus genome: Correlation with viral persistence and disease severity. J Hepatol 2000;33:430-9.

5. Hussain M, Chu CJ, Sablon E et al. Rapid and sensitive assays for determination of hepatitis $B$ virus (HBV) genotypes and detection of HBV precore and core promoter variants. J Clin Microbiol 2003;41:3699-705.

6. Funk ML, Rosenberg DM, Lok AS. World-wide epidemiology of $\mathrm{HBeAg-negative} \mathrm{chronic} \mathrm{hepatitis} \mathrm{B} \mathrm{and} \mathrm{associated} \mathrm{precore} \mathrm{and}$ core promoter variants. J Viral Hepat 2002;9:52-61.

7. Qin Y, Zhang J, Mao R, et al. Prevalence of basal core promoter and precore mutations in Chinese chronic hepatitis B patients and correlation with serum HBeAg titers. J Med Virol 2009;81:807-14.

8. Lin CL, Liao LY, Liu CJ, et al. Hepatitis B genotypes and precore/ basal core promoter mutants in HBeAg-negative chronic hepatitis B. J Gastroenterol 2002;37:283-7.
Mediterranean, Middle East, Eastern Europe, Indian subcontinent, Central Asia, Mongolia, South Africa, Arctic region, Somalia, PapuaNew Guinea, Australian Aboriginals and Indonesia; genotype E focused in West Africa; genotype F focused in Alaska, South America and Central America; genotype $G$ focused in the Europe and North America; and genotype $\mathrm{H}$ focused in Central America (36,37). Two additional genotypes, I and J, have recently been proposed $(38,39)$. However, with more frequent and widespread migration occurring, the geographical distribution of the genotypes is likely shifting. The largest study to date investigating genotype prevalence in North America was by Chu et al in 2003 (9). This study examined 694 patients with chronic HBV infection and found that while all genotypes from A to $G$ were seen, $A$ and $C$ were the most common, with a slight variation in prevalence based on ethnicity. Although none of the HBV genotypes found in our study were directly associated with abnormal laboratory, imaging or biopsy results, because the distribution of PC and BCP mutations varies with HBV genotypes, HBV genotype could be an indirect measure of outcomes, especially if used in combination with PC or BCP mutations as previously shown (40).

Our study shows that the prevalence of PC and BCP mutations in the largest subpopulation of chronically HBV-infected patients (antiHBe patients) is relatively high; this could be attributed to immigration over the past decade. The high prevalence has unique and challenging ramifications from both clinical and public health perspective, requiring more attention and systematic monitoring. The present study was retrospective in nature, relatively small in size and limited in geographical span. Therefore, multicentre prospective observational studies could shed further light on the highly intricate relationship of HBV variants with their human host and may potentially benefit individual patient management.

\section{KEY POINTS}

- The prevalence of PC and BCP mutations in North America needs more recent studies in all jurisdictions.

- PC and BCP mutations are more common than previously known and tend to be, at least indirectly, associated with poor clinical outcomes.

DISCLOSURES: The authors have no financial disclosures or conflicts of interest to declare.

9. Chu CJ, Keeffee EB, Han SH, et al. Prevalence of HBV precore/ core promoter variants in the United States. Hepatology 2003;38:619-28.

10. Minuk GY, Orr PS, Brown R, et al. Pre-core mutant infections in the Canadian Inuit. J Hepatol 2000;33:781-4.

11. Juniastuti, Utsumi T, Aksono EB, et al. Predominance of precore mutations and clinical significance of basal core promoter mutations in chronic hepatitis B virus infection in Indonesia. Biomed Rep 2013;1:522-8.

12. Tseng TC, Liu CJ, Yang HC, et al. Higher proportion of viral basal core promoter mutant increases the risk of liver cirrhosis in hepatitis B carriers. Gut 2015;64:292-302.

13. Chu C-M, Lin C-C, Chen Y-C, et al. Basal core promoter mutation is associated with progression to cirrhosis rather than hepatocellular carcinoma in chronic hepatitis B virus infection. Br J Cancer 2012;107:2010-5.

14. Lin CL, Kao JH. Hepatitis B viral factors and clinical outcomes of chronic hepatitis B. J Biomed Sci 2008;15:137-45.

15. Chen CJ, Yang HI. Natural history of chronic hepatitis B REVEALed. J Gastroenterol Hepatol 2011;26:628-38.

16. McMahon BJ. The natural history of chronic hepatitis B virus infection. Hepatology 2009;49:S45-55.

17. Lin ZH, Xin YN, Dong QJ, et al Performance of the aspartate aminotransferase-to-platelet ratio index for the staging of hepatitis C-related fibrosis: An updated meta-analysis. Hepatology 2011;53:726-36. 
18. Tacke F, Gehrke C, Luedde T, et al. Basal core promoter and precore mutations in the hepatitis $\mathrm{B}$ virus genome enhance replication efficacy of lamivudine-resistant mutants. J Virol 2004;78:8524-35.

19. Amini-Bavil-Olyaee S, Herbers U, Sheldon J, et al. The rtA194T polymerase mutation impacts viral replication and susceptibility to tenofovir in hepatitis B e antigen-positive and hepatitis B e antigen-negative hepatitis $B$ virus strains. Hepatology 2009;49:1158-65.

20. Erhardt A, Reineke U, Blondin D, et al. Mutations of the core promoter and response to interferon treatment in chronic replicative hepatitis B. Hepatology 2000;31:716-25.

21. Hasegawa K, Huang J, Rogers SA, et al. Enhanced replication of a hepatitis $B$ virus mutant associated with an epidemic of fulminant hepatitis. J Virol 1994;68:1651-9.

22. Sato S, Suzuki K, Akahane Y, et al. Hepatitis B virus strains with mutations in the core promoter in patients with fulminant hepatitis. Ann Intern Med 1995;122:241-8.

23. Kosaka Y, Takase K, Kojima M, et al. Fulminant hepatitis B: Induction by hepatitis $\mathrm{B}$ virus mutants defective in the precore region and incapable of encoding e antigen. Gastroenterology 1991;100:1087-94.

24. Omata M, Ehata T, Yokosuka O, et al. Mutations in the precore region of hepatitis $B$ virus DNA in patients with fulminant and severe hepatitis. N Engl J Med 1991;324:1699-1704.

25. Liang TJ, Hasegawa K, Rimon N, et al. A hepatitis B virus mutant associated with an epidemic of fulminant hepatitis. N Engl J Med 1991;324:1705-9.

26. Karayiannis P, Alexopoulou A, Hadziyannis S, et al. Fulminant hepatitis associated with hepatitis $B$ virus e antigen-negative infection: Importance of host factors. Hepatology 1995;22:1628-34.

27. Yuen MF, Tanaka Y, Mizokami M, et al. Role of hepatitis B virus genotypes $\mathrm{Ba}$ and $\mathrm{C}$, core promoter and precore mutations on hepatocellular carcinoma: A case control study. Carcinogenesis 2004;25:1593-8.

28. Kao JH, Chen PJ, Lai MY, et al. Basal core promoter mutations of hepatitis B virus increase the risk of hepatocellular carcinoma in hepatitis B carriers. Gastroenterology 2003;124:327-34.
29. Chou YC, Yu MW, Wu CF, et al. Temporal relationship between hepatitis $\mathrm{B}$ virus enhancer II/basal core promoter sequence variation and risk of hepatocellular carcinoma. Gut 2008;57:91-7.

30. Tong MJ, Blatt LM, Kao JH, et al. Basal core promoter T1762/ A1764 and precore A1896 gene mutations in hepatitis B surface antigen-positive hepatocellular carcinoma: A comparison with chronic carriers. Liver Int 2007;27:1356-63.

31. Miyaura H, Iwata M. Direct and indirect inhibition of Th1 development by progesterone and glucocorticoids. J Immunol 2002;168:1087-94.

32. Fairweather D, Frisancho-Kiss S, Rose NR. Sex differences in autoimmune disease from a pathological perspective. Am J Pathol 2008;173:600-9.

33. Girón-González JA, Moral FJ, Elvira J, et al. Consistent production of a higher TH1:TH2 cytokine ratio by stimulated T cells in men compared with women. Eur J Endocrinol 2000;143:31-6.

34. Okamoto H, Tsuda F, Sakugawa H, et al. Typing hepatitis B virus by homology in nucleotide sequence: Comparison of surface antigen subtypes. J Gen Virol 1988;69:2575-83.

35. Norder H, Hammas B, Löfdahl S, et al. Comparison of the amino acid sequences of nine different serotypes of hepatitis B surface antigen and genomic classification of the corresponding hepatitis B virus strains. J Gen Virol 1992;73:1201-8.

36. Arauz-Ruiz P, Norder H, Robertson BH, et al. Genotype H: A new Amerindian genotype of Hepatitis B virus revealed in Central America. J Gen Virol 2002;83:2059-73.

37. Cooksley WGE. Do we need to determine viral genotype in treating chronic hepatitis B? J Viral Hepat 2010;17:601-10.

38. Tran TT, Trinh TN, Abe K. New complex recombinant genotype of hepatitis B virus identified in Vietnam. J Virol 2008;82:5657-63.

39. Tatematsu K, Tanaka Y, Kurbanov F, et al. A genetic variant of hepatitis $\mathrm{B}$ virus divergent from known human and ape genotypes isolated from a Japanese patient and provisionally assigned to new genotype J. J Virol 2009;83:10538-47.

40. Yang HI, Yeh SH, Chen PJ, et al. Associations between hepatitis B virus genotype and mutants and the risk of hepatocellular carcinoma. J Natl Cancer Inst 2008;100:1134-43. 


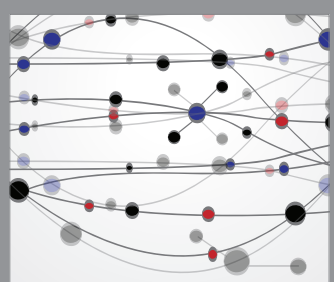

The Scientific World Journal
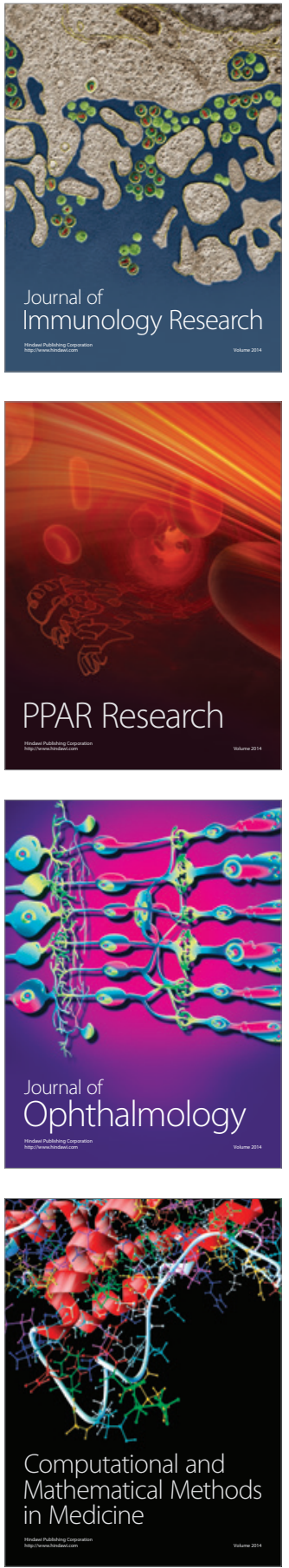

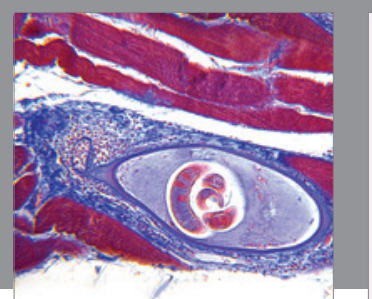

Gastroenterology Research and Practice

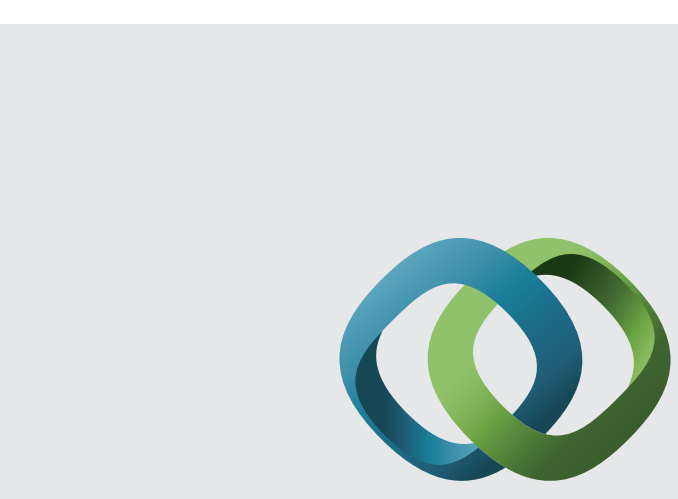

\section{Hindawi}

Submit your manuscripts at

http://www.hindawi.com
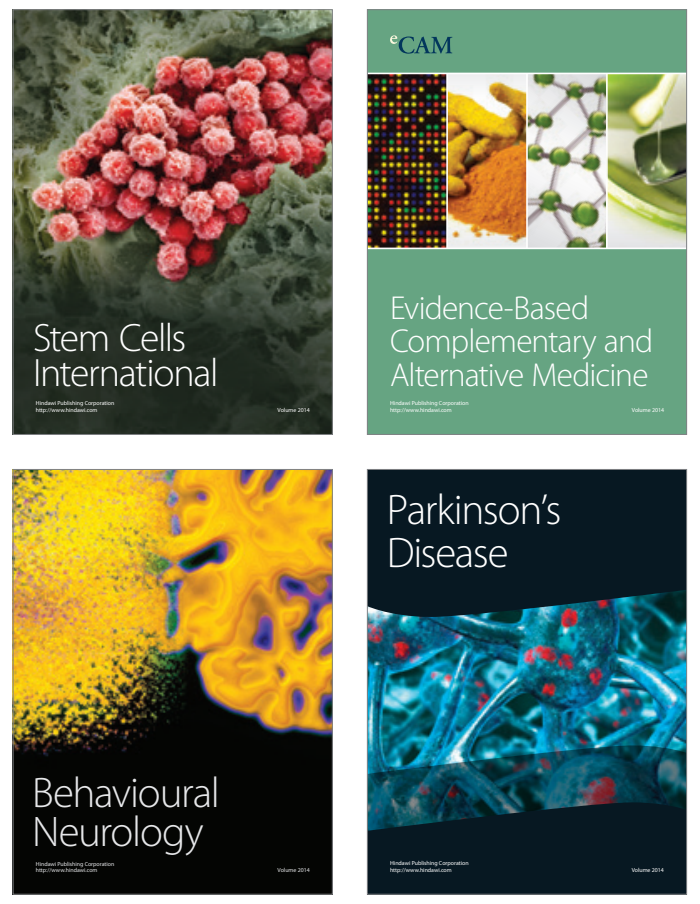
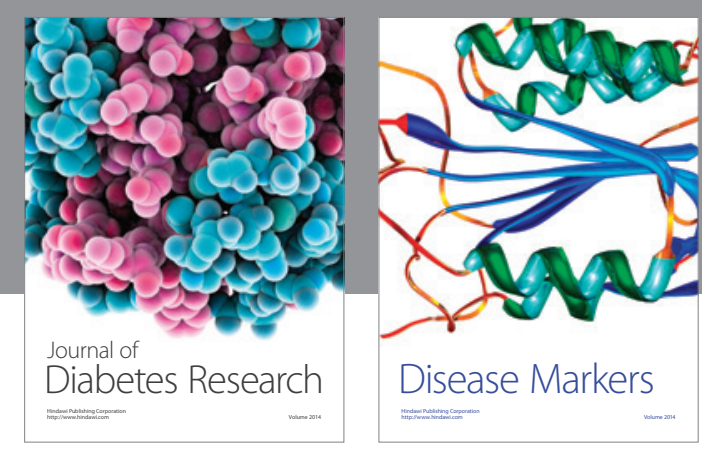

Disease Markers
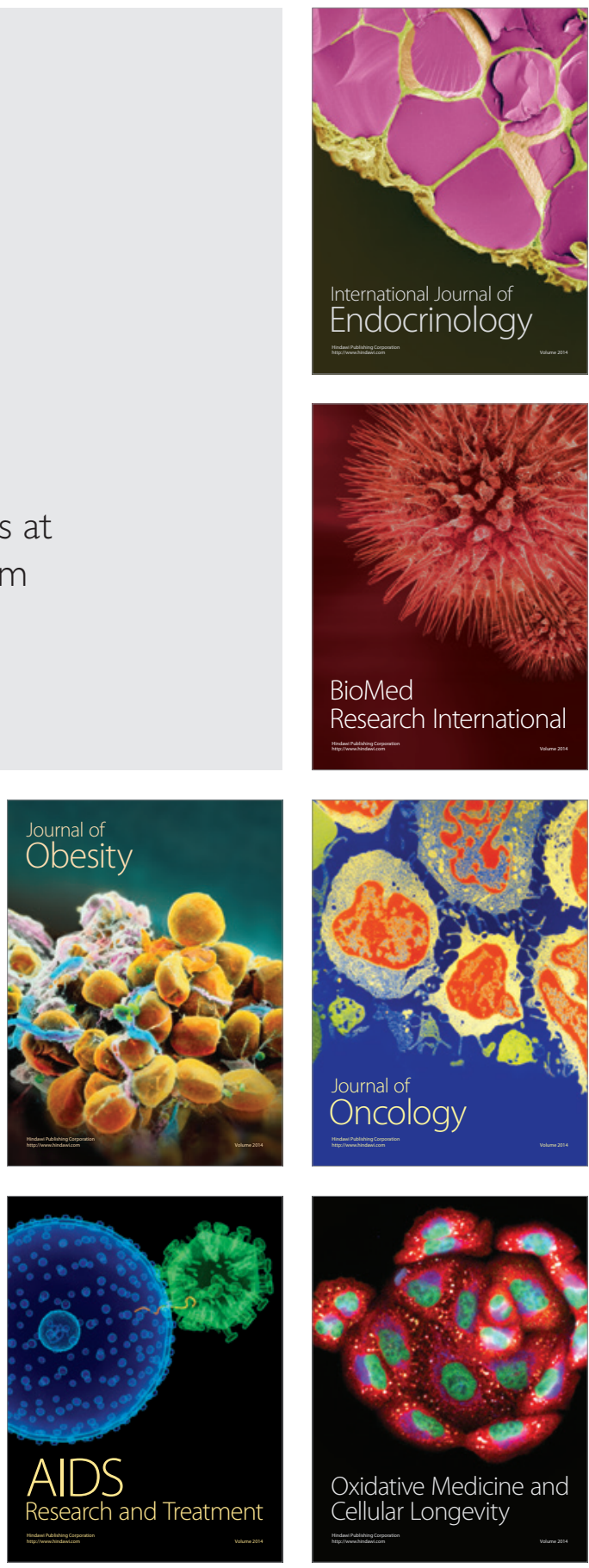